\title{
Entrepreneurial mindset: Examining the contribution of deliberative and implemental mindsets to SME internationalization
}

\author{
Godwin M. Ahimbisibwe ${ }^{1}$, Joseph M. Ntayi², Muhammed Ngoma ${ }^{3}$, Geoffery Bakunda ${ }^{4}$, John C. Munene ${ }^{5}$. \\ Timothy Esemu ${ }^{6}$ \\ ${ }^{1}$ Makerere University Business School, P.O Box 1337, Kampala, Uganda, gahimbisibwe@mubs.ac.ug \\ ${ }^{2}$ Makerere University Business School, P.O Box 1337, Kampala,Uganda,jntayi@mubs.ac.ug \\ ${ }^{3}$ Makerere University Business School, P.O Box 1337, Kampala,Uganda,mngoma@mubs.ac.ug \\ ${ }^{4}$ Makerere University Business School, P.O Box 1337, Kampala, Uganda, gbakunda@mubs.ac.ug \\ ${ }^{5}$ Makerere University Business School, P.O Box 1337, Kampala, Uganda, Jcmunene@mubs.ac.ug \\ ${ }^{6}$ Makerere University Business School, P.O Box 1337, Kampala,Uganda, tesemu@mubs.ac.ug \\ Www.jsbs.org
}

Keywords:

Deliberative mindset, Implemental mindset, Internationalization, SMEs, Uganda.

\section{A B S T R A C T}

The purpose of this study was to establish the contribution of deliberative mindset and implemental mindset to SME (small and medium enterprises) internationalization. This study employed cross-sectional and correlational research designs. Data were collected through a questionnaire survey of exporting SME owners and managers. Data was analyzed with the help of Statistical Package for Social Sciences (SPSS) and SmartPLS. Results suggest that implemental mindset significantly contributes to variances in SME internationalization unlike deliberative mindset. The findings in this study imply that increased levels of internationalization among SMEs in a developing country like Uganda can be achieved by those managers and owners who possess an implemental mindset. This study provides initial empirical evidence of the contribution of deliberative and implemental mindsets to SME internationalization using evidence from Uganda - a developing country.

\section{Introduction}

In this paper, we explore whether each of the entrepreneurial mindset dimensions (deliberative and implemental mindsets) contributes significantly to the internationalization of Small and Medium-sized Enterprises (SMEs) in a developing country context like Uganda. The participation of SMEs in international business has been increasing in the last two decades as they strive to diversify their risks and to remain competitive in the global economy (Misati et al., 2017; Ndiaye et al., 2018; O'Cass, \& Weerawardena, 2009). The available evidence indicates SMEs account for about $52 \%$ of global output and contribute to over $40 \%$ of Gross Domestic Product (GDP) for most world economies (Ayyagari et al., 2011; Ndiaye et al., 2018). Consequently, interest in explaining the participation of these firms that were once considered passive actors has also increased. One area that has emerged strongly is the cognitive research largely focused on establishing the influence of a mindset on the internationalization of small and medium-sized enterprises (Acedo \& Jones, 2007; Felicio et al., 2012; Zahra

Journal of Small Business Strategy

2021, Vol. 31, No. 03, 47-58

ISSN: 1081-8510 (Print) 2380-1751 (Online)

CCopyright 2021 Small Business Institute ${ }^{\circledR}$ et al., 2005). The review of these studies indicates that the individual's cognitive positioning affects the internationalization capabilities of the firm. For instance, Acedo and Jones (2007) post that some mental processes are always present when making decisions to internationalize. Zahra et al. (2005) also observe that cognitive predispositions tend to influence entrepreneurs' responses to their external environments, risk preferences and recognition of emerging foreign market opportunities

While the influence of an individual's cognitive positioning in firm internationalization is documented so far, extant studies have not shown how entrepreneurial mindset (state of mind that orients human conduct towards entrepreneurial activities and outcomes) influences the internationalization of small and medium enterprises (SMEs). Specifically, studies have not explicitly investigated the contribution of each entrepreneurial mindset dimension (deliberative and implemental mindsets) as conceptualized by Mathisen and Arnulf $(2013 ; 2014)$ in the context of SME internationalization. It is not even clear whether both deliberative and implemental mindsets contribute equally to SME internationalization. This is quite surprising since SME internationalization is regarded as an entrepreneurial activity where the multidisciplinary role of entrepreneurs

APA Citation Information: Ahimbisibwe, G. M., Ntayi, J. M., Ngoma, M., Bakunda, G., Munene, J. C., \& Esemu, T. (2021). Entrepreneurial mindset: Examining the contribution of deliberative and implemental mindsets to SME internationalization. Journal of Small Business Strategy, 31(3), 47-58. 
and their mindsets is a key determinant in the foreign expansion process (Felicio et al., 2012). In this study, we acknowledge the existing gap in the literature, and we close it using evidence from Uganda--a developing country. Uganda offers a unique study setting since the international participation of its SMEs that contribute about $20 \%$ of GDP (Hatega, 2007; Ladu, 2019) is very mixed. Some reports indicate that their participation in both regional and international markets has been on the rise since the implementation of structural adjustment programs initiated by the World Bank and the International Monetary Fund (Jaimovich \& Kamuganga, 2010). Other reports indicate that some SMEs in Uganda continue to be slow and less aggressive in exploiting regional and international market opportunities. Particularly there are concerns that even with the opening up of regional markets such as the East African Community (EAC), Common Market for East and Southern Africa (COMESA) and other trade preferential treatments such as the African Growth Opportunity Act (AGOA), most SMEs are still reluctant to fully commercialize their operations in international markets (Nakaweesi, 2016). Given the mixed behavior of SMEs in as far as exploitation of international opportunities is concerned, the study setting seems to be relevant in exploring how the entrepreneur's state of mind influences the internationalization of SMEs in Uganda. Such evidence is important since it provides SMEs in developing countries with information on the state of mind that is relevant to their successful foreign expansion. We achieve our aim through a questionnaire survey of 197 exporting SMEs. Results indicate that implemental mindset contributes significantly to SME internationalization while the deliberative mindset doesn't.

The rest of the paper is organized as follows: Section 2 is the literature review. This is followed by section 3 that provides a detailed methodology. Section 4 presents results. Section 5 is the discussion. Section 6 presents the conclusions and implications of the study. Lastly, section 7 presents limitations and provides directions for future research.

\section{Literature Review}

\section{Theoretical Underpinning}

The concept of entrepreneurial mindset is rooted in the Mindset Theory of Action Phases (Gollwitzer, 1990). The theory assumes that the pursuit of goals is made up of different phases, and each phase is accompanied by a distinct mindset. The first phase is the pre-decisional phase, which is characterized by a deliberative mindset that conditions individuals to evaluate the feasibility of all competing ideas or business opportunities. Accordingly, the deliberative mindset should be able to position an individual to select an opportunity based on the expected benefits (Gollwitzer, 2011). The second phase is the post-decisional phase characterized by the implemental mindset where individuals initiate actions to implement the selected goal (Taylor \& Gollwitzer, 1995). By and large, the deliberative mindset is more linked to procedures of weighing the pros and cons of the available opportunities whereas the implemental mindset is related to actions taken to seize the most feasible opportunities (Armor \& Taylor, 2003; Gollwitzer 1990; McMullen \& Kier, 2016). By extension, we posit that internationalizing SMEs with entrepreneurial-inclined managers and owners should be well-positioned to evaluate competing international business opportunities and design appropriate actions to seize them. In line with this reasoning, it is possible to suggest that the decisions taken during the process of the international expansion of SMEs will largely depend on the mental positioning of their owners or managers at a given point in time, and this will influence the speed of market entry, the scope of operations in international markets and the extent of involvement in the foreign markets. This supposition is consistent with the views of Ngoma et al. (2017), who allude to the fact that the entrepreneurial positioning of individuals has the potential to influence the international expansion of SMEs.

Unlike in the past where internationalization was considered to be a preserve for large multinational companies, evidence indicates that this view is no longer valid as many SMEs have successfully set up activities beyond their home markets (Ruzzier et al., 2006). The term "internationalization" is associated with the international expansion of a firm's economic activities across national borders. Whereas this is true, several definitions have been advanced in international business-related studies to try and explain its nature. For instance, Johanson and Mattsson (1993) define internationalization as the process of adapting a firm's operations (strategy, structure, and resources) to international activities. Internationalization is also defined by Calof \& Beamish (1995) as a process in which firms increase commitment to foreign activities in foreign markets. Oviatt and McDougall (2005) take an entrepreneurial perspective and define internationalization as the discovery, enactment, evaluation, and exploitation of opportunities across national borders to create future goods and services. Welch \& Luostarinen, (1993) describe internationalization as the outward movement of a firm's international operations. Given the context of this study, the definition by Welch and Luostarinen, (1993) seems to be more appropriate to depict SME internationalization in Uganda. We adopt this definition because of two reasons. First, consistent with most studies on SME internationalization, this study concentrates 
on Uganda's exporting SMEs that largely produce domestically and sell/export their products or services outside the national borders thus capturing the outward outlook emphasized in the definition. Secondly, most SMEs inherently suffer from resource poverty, and therefore the outward movement where firms simply produce domestically and export seems to be the cheapest way to expand and access foreign markets when compared to high-cost foreign market entry modes such as Joint ventures and wholly-owned subsidiaries (Tesform \& Lutz, 2006)

\section{Deliberative Mindset, Implemental Mindset and SME Internationalization.}

Conceptually, entrepreneurial mindset is a multidimensional concept composed of a deliberative mindset and an implemental mindset (Mathisen \& Anulf, 2013; Naumann, 2017). Although there has been little research addressing how these mindsets directly contribute to firm internationalization, several lines of investigation suggest that these could have a positive contribution to both predictions and outcomes (Armor \& Taylor, 2003). In line with this view, it is possible to postulate that both deliberative and implemental mindsets could have a significant influence on the internationalization of SMEs. First, the deliberative mindset which conditions individuals to evaluate the desirability and feasibility of the available competing opportunities (Taylor \& Gollwitzer, 1995) could be critical in the internationalization process of SMEs. This assertion is based on the view that international expansion is characterized by many businesses and individuals with such a state of mind may be able to take decisions in international markets based on informed evaluation of the opportunities at hand. This evaluative mindset drives individuals to pursue the best international business opportunities since they tend to evaluate all potential opportunities from a set of competing ideas (Gregoire et al., 2008; Williams, 2010). Because of this, Wood and Williams (2014) suggest that whereas identifying an opportunity is a necessary step, it is insufficient for entrepreneurial action. The authors posit that after the identification of an opportunity, managers and entrepreneurs must evaluate the viability of an opportunity before taking any action. Indeed, Nadikarni et al. (2006) postulate that the mindset is an important human resource in international success because firms are likely to use the mindsets of their managers and owners to scan international opportunities, diagnose constraints imposed by the foreign markets and guide alternative internationalization choices.

Regarding implemental mindset, there are submissions that the possession of such state of mind will orient individuals towards formulating actions necessary to seize the perceived opportunities (Mathisen \& Arnulf, 2014; McMullen \& Kier, 2016; Naumann, 2017). Based on this view, it is possible to suggest in this study that implemental-minded individuals are well-positioned to exploit opportunities in international markets. This understanding is consistent with the submissions by Gregoire et al. (2010), who indicated that organizations operate in complex and dynamic environments that are increasingly characterized by rapid and significant changes where gains in profit, growth and competitive positioning can only be made by those individuals and organizations that can initiate actions aimed at exploiting the opportunities that arise in such changing environments. Thus, we extend this argument and assert that SMEs will be able to generate substantial returns and venture into multiple markets by initiating actions required to exploit the perceived opportunities in such an environment. In support, Lindstrand and Hanell (2017) stress that actions related to the exploitation of international business opportunities determine firm growth and international expansion of SMEs. From the foregoing discussion, we believe that SME managers with a deliberative mindset will be able to explore international markets. We also argue in this study that SME managers with implemental mindsets are likely to explore international markets. Thus, we hypothesize that:

H1. A deliberative mindset significantly contributes to SME internationalization.

H2. An implemental mindset significantly contributes to SME internationalization.

\section{Method}

\section{Research Design, Population, and Sample Size}

This study's design was cross-sectional and correlational. We adopted a cross-sectional design because data was collected at a particular point in time. The study was correlational because it aimed at establishing relationships between the study variables. This study targeted a population of 390 exporting SMEs in the central districts of Uganda (Kampala, Wakiso, and Mukono) where most exporting SMEs (Uganda Export Promotions Board Database, 2018) are. The Yamane (1973) sample size selection model $n=N /$ $1+\mathrm{N}(\mathrm{e})^{2}$ was utilized to determine the sample size. Based on this, a sample size of 197 exporting SMEs was generated. We used a sample random sampling technique to select the particular exporting SMEs using a table of random numbers to pick the required sample of 197 firms. Our unit of analysis was an SME while our units of inquiry were SME owners and managers. Data was therefore aggregated to a 


\section{\& T. Esemu}

level of an SME. Out of the 197 exporting SMEs sampled, usable responses were received from 144 exporting SMEs, representing a response rate of $73 \%$. The high response rate is attributed to the ample time given to the respondents to complete the questionnaire. Respondents were given three months to complete the questionnaire. However, after every two weeks, respondents would be contacted to find out whether the questionnaires with them had been completed.

Results from the survey indicate that the majority of the respondents were males (75.1\%), the majority were aged between 27 to 37 years $(51.3 \%)$, the majority had attained a bachelor's degree (44.4\%) and the majority were managers $(76.7 \%)$. The results further indicate that the majority of the SMEs that participated in this study were active in the manufacturing sector $(38.9 \%)$. The majority $(37.5 \%)$ had operated in international business for 6-10 years. The majority $(59.7 \%)$ employed between $1-49$ employees, which fit in the category of small-sized firms while the rest (40.3\%) employed between 50- 249 employees, fitting in the category of medium-sized enterprises. The Respondents' and firm characteristics are indicated in Table 1.

This study used a questionnaire with close-ended questions. The questionnaire was used because it is appropriate for collecting data from a large sample (Sekaran, 2003). The questionnaire was also used because of its capacity to capture primary respondents' opinions. The questionnaire contained close-ended questions. Whereas open-ended questionnaires are known for enabling respondents to express their opinions on the subject matter as much as possible, we intended to obtain the mean ratings of the statements in the questionnaire, and therefore, open-ended responses were inappropriate.

The reliability and validity of the measurement scales were computed using SmartPLS statistical software. For reliability values, we relied on composite reliability estimates and all the values were found to be above 0.7 (Deliberative Mindset $=0.88$, Implemental Mindset $=0.87, \mathrm{SME}$ internationalization $=0.89$ ), as shown in Table 2. Moving forward, we tested for convergent validity to assess the degree to which measures of the same construct were correlated. We followed the criteria by Fornell and Larcker (1981), which posits that to ascertain convergent validity, the factor loadings should be above 0.5 and the Average Variance Explained (AVE) should exceed the cut-off point of 0.5 . The results in Table 2 indicate that these criteria were met confirming that the measures of each of the study variables were sufficiently correlated. To establish whether the constructs were conceptually different from each other, a discriminant validity test was performed. We considered the Heterotrait-Monotrait ratio of correlations (HTMT) criterion as recommended by Henseler et al. (2015). The HTMT test was preferred since the most celebrated Fornell-Larcker test is not accurate enough in detecting discriminant validity (Henseler et al., 2015). Accordingly, the value of two reflective constructs should be below 0.85 (Kline, 2011). The results in Table 3 indicate that all the HTMT values were below 0.85 , ascertaining that the constructs were distinctively different from each other.

\section{Measurements of Variables}

In measuring the study variables, we based this process on the previous studies. The items for the independent variables were anchored on a six-point Likert scale ranging from 1 "strongly disagree" to 6 "strongly agree" to avoid response indecision associated with middle neutral points (Ntayi et al., 2012) while those of the dependent variable were anchored on a six-point interval scales to match the scale of predictor variables.

The dependent variable for this study is SME internationalization, which we operationalized in terms of speed, scale, and scope to capture the outward shift of SMEs' foreign operations. This is consistent with previous studies (see, for example, Bakunda, 2003; Lu \& Beamish, 2001; Hsieh et al., 2019; Ngoma \& Ntale, 2014; Sullivan, 1994). We defined speed as the length of time between the firm's inception and its first foreign activities. We defined scale as the extent to which a firm is exposed to international markets compared to the domestic market. Finally, we defined scope as the territorial spread/coverage of the firm.

The independent variables are the deliberative mindset and implemental mindset. We measured deliberative mindset based on measures such as 'we reflect whether we have the financial capacity for international operations.' We defined a deliberative mindset as the state of mind that is oriented towards evaluating the feasibility of competing opportunities. For implemental mindset, we used measures such as, "we make sure that enough finances are mobilized to pursue our business ideas in foreign markets" to operationalize it. Such measures were adopted from the works of Mathisen \& Arnulf (2014) and modified to fit in the context of this study. We defined implemental mindset as the state of mind oriented towards initiating actions to seize the available business opportunities.

We controlled for firm size, sector, and export experience to ensure that our model only represented the hypothesized relationships. The firm size (Ngoma, 2009; Yang et al., 2015), export experience (Andersen \& Buvik, 2002; Tolstoy, 2019), sector (Lindstrand \& Hanell, 2017) have largely been used as control variables in international business studies. Firm size was measured by the number of permanent full-time employees in the firm, the export ex- 
Table 1

Respondents' and firm characteristics

\begin{tabular}{|c|c|c|c|}
\hline \multicolumn{2}{|c|}{ Individual Characteristics } & Frequency & Percent \\
\hline \multirow{3}{*}{ Gender } & Male & 142 & 75.1 \\
\hline & Female & 47 & 24.9 \\
\hline & Total & 189 & 99.5 \\
\hline \multirow{6}{*}{ Age } & $18-26$ & 16 & 8.5 \\
\hline & $27-37$ & 97 & 51.3 \\
\hline & $38-48$ & 43 & 22.8 \\
\hline & $49-59$ & 30 & 15.9 \\
\hline & $60 \&$ Above & 3 & 1.6 \\
\hline & Total & 189 & 100.0 \\
\hline \multirow{6}{*}{ Education Level } & Secondary & 12 & 6.3 \\
\hline & Certificate & 17 & 9.0 \\
\hline & Diploma & 46 & 24.3 \\
\hline & Bachelor's Degree & 84 & 44.4 \\
\hline & Masters \&Above & 30 & 15.9 \\
\hline & Total & 189 & 100.0 \\
\hline \multirow{4}{*}{ Position } & Owner & 19 & 10.1 \\
\hline & Manager & 145 & 76.7 \\
\hline & owner-Manager & 25 & 13.2 \\
\hline & Total & 189 & 100 \\
\hline \multicolumn{2}{|c|}{ Firm Characteristics } & Frequency & Percent \\
\hline \multirow{6}{*}{ Sector } & Agriculture & 36 & 25.0 \\
\hline & Manufacturing & 56 & 38.9 \\
\hline & Services & 31 & 21.5 \\
\hline & Arts and craft & 19 & 13.2 \\
\hline & Minerals \& Rare Earth & 2 & 1.4 \\
\hline & Total & 144 & 100.0 \\
\hline \multirow{7}{*}{ Export Experience } & $1-5$ Years & 31 & 21.5 \\
\hline & 6-10 Years & 54 & 37.5 \\
\hline & $11-15$ Years & 30 & 20.8 \\
\hline & 3.50 & 1 & .7 \\
\hline & 16-20 Years & 16 & 11.1 \\
\hline & $21 \&$ above Years & 12 & 8.3 \\
\hline & Total & 144 & 100.0 \\
\hline
\end{tabular}


Table 2

Factor loadings, composite reliability (CR) and average variance explained (AVE)

\begin{tabular}{|c|c|c|c|c|}
\hline Constructs & Items & $\begin{array}{l}\text { Factor } \\
\text { Loadings }\end{array}$ & CR & AVE \\
\hline \multirow[t]{4}{*}{ Deliberative Mindset } & & & 0.828 & 0.616 \\
\hline & $\begin{array}{l}\text { We reflect on whether we have the financial capacity needed } \\
\text { for international operations }\end{array}$ & 0.849 & & \\
\hline & $\begin{array}{l}\text { We always consider whether we have the skills necessary to } \\
\text { undertake the available international opportunities }\end{array}$ & 0.745 & & \\
\hline & $\begin{array}{l}\text { We reflect on both negative and positive information when } \\
\text { making decisions to undertake a given business opportunity }\end{array}$ & 0.757 & & \\
\hline \multirow[t]{3}{*}{ Implemental Mindset } & & & 0.791 & 0.654 \\
\hline & $\begin{array}{l}\text { We make sure that enough finances are mobilized to pursue } \\
\text { our business ideas } \\
\text { in foreign markets }\end{array}$ & 0.788 & & \\
\hline & $\begin{array}{l}\text { We obtain the necessary know-how needed for international } \\
\text { expansion }\end{array}$ & 0.829 & & \\
\hline \multirow[t]{5}{*}{ SME Internationalization } & & & 0.823 & 0.695 \\
\hline & $\begin{array}{l}\text { How long did it take this company to make its first entry into } \\
\text { international markets? }\end{array}$ & 0.788 & & \\
\hline & $\begin{array}{l}\text { How long did it take this company to open up its first sales } \\
\text { foreign branch }\end{array}$ & 0.808 & & \\
\hline & $\begin{array}{l}\text { When compared to domestic sales, how much do export sales } \\
\text { contribute to the overall sales? }\end{array}$ & 0.876 & & \\
\hline & $\begin{array}{l}\text { How many countries in the world are you currently exporting } \\
\text { to? }\end{array}$ & 0.859 & & \\
\hline
\end{tabular}

Table 3

Heterotrait-Monotrait Ratio (HTMT)

\begin{tabular}{lccc}
\hline \multicolumn{1}{c}{ Item } & Deliberative Mindset & $\begin{array}{c}\text { Implemental } \\
\text { Mindset }\end{array}$ & SME Internationalization \\
\hline Deliberative Mindset & 1 & & \\
Implemental Mindset & 0.19 & $\mathbf{0 . 2 3}$ & 1 \\
SME Internationalization & 0.41 & \\
\hline
\end{tabular}

Note(s): The figures in bold are HTMT values. Threshold of HTMT is $<0.85$. 
perience was measured by the number of years previously spent in exporting, and the sector was measured by the five sectors of Agriculture and agro-processing, manufacturing, services, arts, and crafts as well as minerals and rare earth as specified by Uganda Export Promotions Board.

\section{Control for Common Methods Bias}

To minimize bias from the respondents, we controlled for common methods bias common in survey-based studies (Gorrell et al., 2011). Accordingly, method biases are a problem because they are one of the main sources of measurement error that normally threaten the validity of the conclusions made about the relationships. We controlled the bias by following the procedural recommendations advanced by Podsakoff et al. (2003). Thus, we targeted at least three respondents from each firm to eliminate social desirability bias. We also ensured that the dependent variable and independent variables were not similar in content. Also, we assured the respondents that there were no right or correct answers to prevent them from editing the initial responses to be more socially desirable. More so, we avoided double-barreled questions. Lastly, we tried to keep the questions as simple, specific, and precise as possible.

\section{Descriptive Statistics}

\section{Results}

The descriptive statistics in Table 4 indicate the level of perceptions on both the dependent and the independent variables. Statistics on SME internationalization (dependent variable) indicate a mean of 3.83 out of a maximum of 6, suggesting that managers and owners in Uganda perceive internationalization among their exporting SMEs to be above average $(>50 \%)$. For the independent variables (Deliberative mindset and Implemental mindset), the results indicate mean scores of 4.78 and 4.47 on a scale of $1-6$, suggesting that more than $75 \%$ of managers/owners of exporting SMEs in Uganda recognize high levels of both deliberative and implemental mindsets among their firms. The mean scores for the main study variables fall between 3.93 and 4.78 on an anchor of a six-point scale. In comparison to the mean, the standard deviations range from 0.61 to 0.70 . Given that the standard deviations as compared to the mean values are small, the results imply that the study sample is an accurate reflection of the population and the participants in this study have a closer understanding of the study variables.

Table 4

Descriptive statistics for independent variables and the dependent variable

\begin{tabular}{lcccccc}
\hline \multicolumn{1}{c}{ Item } & $\boldsymbol{N}$ & Min & Max & Mean & SD & Median \\
\hline Deliberative Mindset & 144 & 3.00 & 5.88 & 4.78 & 0.61 & 4.75 \\
Implemental Mindset & 144 & 2.68 & 5.47 & 4.47 & 0.70 & 4.68 \\
SME Internationalization & 144 & 2.30 & 5.32 & 3.93 & 0.69 & 3.82 \\
Source: Primary data & & & & & & \\
\hline
\end{tabular}

\section{Correlation Analysis}

We ran the Pearson correlation coefficients as shown in Table 5. We found that deliberative mindset is not significantly associated with SME internationalization $(r=0.044$, $p>0.01)$. This means that positive changes in deliberative mindset may not necessarily improve SME internationalization. We found that implemental mindset is significantly associated with SME internationalization $(r=0.367, p$ $<0.01)$. This means that a positive change in implemental mindset may cause positive changes in SME internationalization.

\section{Hierarchical Analysis}

Having obtained the correlation analysis results which provide preliminary evidence on the association among the study variables, we ran the hierarchical regression analysis to establish the contribution of each independent variable to the dependent variable. Hierarchical regression analysis was preferred since it can analyze the effect of predictor variables on the dependent variable while controlling for confounding factors (Field, 2009). Besides, hierarchical regression can establish the incremental contribution of each predictor variable to the dependent variable (Sekaran, 2003). Moving forward, we entered the control variables 
Table 5

Correlation analysis results

\begin{tabular}{lccc}
\hline \multicolumn{1}{c}{ Variables } & $\begin{array}{c}\text { Deliberative } \\
\text { Mindsets }\end{array}$ & $\begin{array}{c}\text { Implemental } \\
\text { Mindsets }\end{array}$ & SME Internationalization \\
Deliberative Mindsets & 1 & 1 & \\
Implemental mindsets & 0.078 & $.367^{* *}$ & 1 \\
SME Internationalization & 0.044 & \\
\hline
\end{tabular}

**. Correlation is significant at the 0.01 level (2-tailed).

into model I. Model 1 is the baseline model. We found that the control variables and deliberative mindset are not significant. The control variables included the sector of belongingness, size of the exporting firm, and experience of the exporting firm. The control variables only contributed $1.8 \%$ of the variances in SME internationalization. The finding that control variables are not significant is an indicator that our model is not affected by the confounding factors. In Model 2, we entered the deliberative mindset. We find that deliberative mindset is not significant and thus contributes an additional $0.6 \%$ of the variance in SME internationalization. Model 3 is our final model. In Model 3, we entered an implemental mindset, and we found that it was significant. Implemental mindset contributes to $11.8 \%$ together with the deliberate mindset and the control variables to variances in SME internationalization. This means that implemental mindset comes with an additional 9.4\%. The regression analysis shows that $\mathrm{H} 1$ is not supported, but $\mathrm{H} 2$ is supported. The hierarchical analysis results are presented in Table 6.

Table 6

Hierarchical regression analysis results

\begin{tabular}{|c|c|c|c|}
\hline Item & $\begin{array}{c}\text { Model 1 } \\
\text { Beta Coefficients }\end{array}$ & $\begin{array}{c}\text { Model 2 } \\
\text { Beta Coefficients }\end{array}$ & $\begin{array}{c}\text { Model 3 } \\
\text { Beta Coefficients }\end{array}$ \\
\hline Constant & 3.706 & 2.296 & 2.128 \\
\hline
\end{tabular}

Independent Variables

Deliberative

Implemental

\section{Control Variables}

Sector

Firm Size

Export Experience
.021

.001

.031

Model Summary

F

$R^{2}$

Adjusted $R^{2}$

$F$ Change

$R^{2}$ change

Durbin-Watson
.146

.003

.018

.146

.003
.020

.008

.034

.175

.005

.024

.264

.002
.026

.147

.083

Note(s): **P=0.01 


\section{Discussion}

The study sought to establish the contribution of entrepreneurial mindset dimensions (deliberative mindset and implemental mindset) to SME internationalization in Uganda. It is evident that the deliberative mindset does not contribute significantly to SME internationalization $(r=0.044$, $\mathrm{p}>0.01)$. These results suggest that as SME managers/ owners increasingly orient their minds towards deliberating on the feasibility of every available opportunity in international markets, their level of internationalization does not change significantly. Our findings seem to be at variance with the previous studies (Gregoire et al., 2008; Nadikarni et al., 2006) who had earlier observed that seizing international opportunities requires an evaluative mindset to be able to pursue the best alternative out of the several potential opportunities available in international markets. However, our results are consistent with the view of Mathisen and Arnulf (2013), who indicated in their findings that deliberations on the feasibility of competing opportunities may encourage more thinking and doubt subsequently increasing the gap between intention and action. In line with this reasoning, it's possible to imagine that the key players in Uganda's exporting SMEs tend to evaluate the available competing opportunities but perhaps fail to take steps to exploit the most viable one.

The findings also reveal that that implemental mindset is positively and significantly related to SME internationalization in Uganda $(r=0.367, p<0.01)$. This means that a positive change in implemental mindset is associated with a positive change in SME Internationalization. In the context of this study, these results imply that SME managers and owners who mobilize the necessary financial resources and recruit the employees with skills and know-how within their exporting firms will realize the high speed of foreign market entry, will expand into several markets, and will be able to generate substantial revenues from foreign markets. Consistent with these findings, our study lends support to earlier studies by Lindstrand \& Hanell (2017), who observed that actions oriented to the exploitation of foreign opportunities determine the international expansion of SMEs.

\section{Conclusion and Implications}

The contribution made by deliberative mindset and implemental mindset to SME internationalization is now known. Among the dimensions of an entrepreneurial mindset (deliberative mindset and implemental mindset), it's the implemental mindset that has a significant positive relationship with SME internationalization in Uganda. This suggests that higher levels of SME internationalization are dependent upon those managers/owners who are oriented towards initiating actions needed to pursue foreign expansion. Thus actions, such as mobilization of financial resources and obtaining the necessary know-how, are very critical in enhancing the level of internationalization among SMEs in Uganda. These actions not only leverage firms to enter into international markets faster but also to generate substantial revenues from sales as well as to venture into multiple markets.

This paper, therefore, offers several implications. Theoretically, the study documents that only implemental mindset significantly contributes to SME Internationalization. Our results imply that SMEs can internationalize better with managers/ owners who possess an implemental mindset.

From the practical perspective, our results reveal that successful SME internationalization in developing countries and particularly in Uganda can be achieved by entrepreneurs who are more inclined towards taking actions needed to exploit the identified international business opportunities. Therefore, SMEs should pursue actions that are related to the mobilization of adequate finances. This can be done by creating working relationships with banks to provide export credit as well as short-term loans. More so, lobbying the government to provide cheaper sources of capital can be pursued by the managers and owners of SMEs. Through financial access, SMEs will be well-positioned to produce products that meet the expected standards in international markets, will facilitate improvement in production processes, will ensure constant supply as well as lessen product rejection due to poor quality. Additionally, SMEs need to seek the right skills to be able to expand their operations beyond their national borders. The skills could be in line with production, marketing, market information gathering, and analysis as well as product quality management. These skills are critical in ensuring constant production, production of high-quality products as well as keeping pace with the changes in international markets. With such actions, SMEs will be able to expand to multiple markets, generate substantial returns from export sales, and above all expand faster into foreign markets.

For policymakers in Uganda, it is evident from our findings that successful internationalization is contingent on implementing actions oriented towards exploiting international opportunities. Therefore, there is a need for policymakers to augment the efforts of entrepreneurial SMEs to extend their operations in foreign markets. Particularly the government should acknowledge the role of information in the process of opportunity evaluation and make it easier for entrepreneurs to effortlessly access it. This is particularly so since opportunity exploitation requires information for initial evaluation. Thus, deliberate efforts aimed at provid- 
G. M. Ahimbisibwe, J. M. Ntayi, M. Ngoma, G. Bakunda, J. C. Munene, \& T. Esemu

ing relevant export-related information within the relevant government institutions like Uganda Export Promotions Board (UEPB) should be pursued. This information could be related to market opportunities, competition in the target markets, regulations, as well as the foreign customer values, tastes, and preferences. Access to such information by the exporting SMEs will go a long way in forming a strong basis on which firms can evaluate their abilities on whether to pursue certain foreign opportunities or not. Additionally, it should be noted that exploitation of opportunities in international markets requires the installation of the improved production process, conducting foreign market research, and meeting standards which all require a substantial financial investment. The government of Uganda can do this by exempting taxes on imported machinery as well as by providing relatively cheap export credit to smoothen international expansion. This is very critical since in most cases opportunity exploitation among SMEs is dependent upon the finances at hand and the possibility of accessing the additional resources when needed.

\section{Limitations and Future Research}

This study has some limitations that should be addressed in future research. First, we only considered SMEs that use exporting as their form of internationalization. Whereas exporting is the most preferred form of international expansion among SMEs, it's important to note that these firms utilize other forms of foreign market entry such as franchising, licensing, Joint ventures, and wholly-owned subsidiaries to access international markets. Thus, the extent to which the findings of this study can be generalized to other SMEs that use other modes of foreign expansion is not known. Second, the independent variables (Deliberative mindset and Implemental mindset) predicted $11.8 \%$ of SME internationalization in Uganda. This suggests that about $88 \%$ of SME internationalization in Uganda can be explained by other factors that were not part of this study. Future studies may consider other factors that are not part of this study to explain the internationalization of SMEs in Uganda. Lastly, a cross-sectional survey was conducted in this study. This constrains our ability to make causal references between the variables used in this study since the views held by individuals may change over the years. Thus, future studies might benefit from the use of longitudinal studies to establish if there are causal links between deliberative mindset, implemental mindset, and SME internationalization.
Journal of Small Business Strategy / Vol. 31, No. 3 (2021) / 47-58

\section{References}

Acedo, J. F., \& Jones, V. M. (2007). Speed of internationalization and entrepreneurial cognition: Insights and a comparison between international new ventures, exporters and domestic firms. Journal of World Business, 42(3), 236-252.

Andersen, O., \& Buvik, A. (2002). Firms' internationalization and alternative approaches to the international customer/market selection. International Business Review, 11(3), 347-363.

Armor, D. A., \& Taylor, S. E. (2003). The effects of mindset on behavior: Self-regulation in deliberative and implemental frames of mind. Personality and Social Psychology Bulletin, 29(1), 86-95.

Ayyagari, M., Demirgüç-Kunt,A., \& Maksimovic, V. (2011). Small vs. young firms across the world - contribution to employment, job creation, and growth. The World Bank Development Research Group, Working Paper 5631.

Bakunda, G. (2003). Explaining firm internationalization in Africa using the competence approach. Journal of African Business, 4(1), 57-85.

Calof, J., \& Beamish, P. W. (1995). Adapting to foreign markets: Explaining internationalization. Business Review, 4(2), 115-31.

Felicio, J. A., Caldeirinha, V. R. \& Rodrigues, R. (2012). Global mindset and the of small: The importance of the characteristics of entrepreneurs. International Entrepreneurship and Management Journal, 8(4), 467-485.

Field, A. (2009). Discovering statistics using SPSS (3rd ed.). Sage.

Fornell, C., \& Larcker, D. F. (1981). Evaluating structural equation models with unobservable variables and measurement error. Journal of Marketing Research, 18(1), 39-50.

Gollwitser, P.M. (1990). Action phases and mind-sets. In E. T. Higgins, \& R. M. Sorrentino (Eds.), The handbook of motivation and cognition: foundations of social behavior. (Vol 2, pp.52-92). Guilford Press.

Gollwitzer, P. M. (2011). Mindset theory of action phases. In P. Van Lange, A. Kruglanski, \& E. T. Higgins (Eds.), Handbook of Theories of Social Psychology (Vol. 1, pp. 526-546). Sage Publications.

Gorrell, G., Ford, N., Madden, A., Holdridge, P. \& Eaglestone, B. (2011). Countering method bias in questionnaire-based user studies. Journal of Documentation, 67(3), 507-524.

Gregoire, D. A, Barr, P. S, \& Shepherd, D. A. (2010). Cog- 
nitive processes of opportunity: The role structural alignment. Organisation Science, 21(2), 413-431.

Gregoire, D. A., Williams, D. W., Oviatt, B. M. (2008). Early internationalization of new ventures: What matters? Frontiers of Entrepreneurship Research, 28(18), 2.

Hatega, G. (2007). SME development in Uganda. Uganda Industrial Research Institute. www.uiri.org/sites/uiri. org/mysms/content/e773/e813/SMEDevelopment. pdf

Henseler, J., Ringle, C. M., \& Sarstedt, M. (2015). A new criterion for assessing discriminant in variance-based structural equation modeling. Journal of the Academy of Marketing Science, 43(1), 115-135.

Hsieh, L., Child, J., Naroozc, R., Elbannad, S., Karmowskae, J., Marinova, S., Puthusserryg, P., Tsaih, T., \& Zhang, Y. (2019). A multidimensional perspective of SME internationalization speed: The influence of entrepreneurial characteristics. International Business Review, 28(2), 268-283.

Jaimovich, D., \& Kamuganga, D. (2010). Three decades of trade policy in Uganda: Two generations of reforms in the quest to become part of the global market. FREIT Working Paper \#437. FREIT.

Johanson, J., \& Mattsson, L. G. (1993). Internationalization in industrial systems - a network approach, strategies in global competition. In P. J. Buckley, \& P. N. Ghauri (Eds.), The internationalization of the firm: $A$ reader. (pp. 303-22). Academic Press.

Kline, R. B. (2011). Principles and practice of structural equation modeling. Guilford Press.

Ladu, I. M. (2019, December 3). What is at stake for small, medium enterprises in single African market. Daily Monitor. https://www.monitor.co.ug

Lindstrand, A., \& Hanell, S. M. (2017). International and market-specific social capital effects on international opportunity exploitation in the internationalization process. Journal of World Business, 52(5), 653-663.

Lu, J. W., \& Beamish, P. W. (2001). The internationalization and performance of SMEs. Strategic Management Journal, 22(6-7), 565-586.

Mathisen. J., \& Arnulf. K. J. (2013). Competing mindsets in entrepreneurship: The cost of. The International Journal of Management Education, 11(3), 132-141.

Mathisen. J., \& Arnulf. K. J. (2014). Entrepreneurial mindsets theoretical foundations and properties of a mindset scale. The International Journal of Management and Business, 5(1), 81- 104.

McMullen, J. S., \& Kier, A. S (2016). Trapped by the entrepreneurial mindset: Opportunity seeking and escalation of commitment in the mount everest disaster. Journal of Business Venturing, 31(6), 663-686.
Misati, E., Walumbwa, F. O., Lahiri, S., \& Kundu, S. K. (2017). The internationalization of African small and medium enterprises (SMEs): A South-North pattern. Africa Journal of Management, 3(1), 53-81.

Nadkarni. S, Perez D. P. , \& Morganstein, B. (2006). Mindsets and internationalisation success: An exploratory study of the British retail grocery industry. Organization Management Journal, 3(2), 139-154.

Nakaweesi, D. (2016). Why Uganda is not exporting enough products. The Daily Monitor. https://www. monitor.co.ug

Naumann, C. (2017). Entrepreneurial mindset: A synthetic literature review, Entrepreneurial Business \& Economic Review, 5(3), 150-172.

Ndiaye, N., Razak, L., Nagayev, R., \& Ng, A. (2018). Demystifying small and medium enterprises' (SMEs) performance in emerging and developing economies. Borsa Istanbul Review, 18(4), 269-281.

Ngoma, M. (2009). Internationalisation of service firms in less developed countries. A study of Uganda service organisations. Doctoral Thesis, Makerere University.

Ngoma, M., Abaho, E., Nangoli, S., \& Kusemererwa, C. (2017) Internationalisation of SMEs: Does entrepreneurial orientation matter? World Journal of Entrepreneurship, Management and Sustainable Development, 13(2), 96-113.

Ngoma, M., \& Ntale, P. D. (2014). Network competence and internationalization of service firms in Uganda. Asian Journal of Science and Technology, 5(3), 160170.

Ntayi, M. J., Ngoboka, P., Mutebi, H., \& Sitenda, G. (2012). Social value orientation and regulatory compliance in Ugandan public procurement. International Journal of Social Economics, 39(11), 900-920.

O'Cass, A., \& Weerawardena, J. (2009). Examining the role of international entrepreneurship, innovation and international market performance in SME internationalization. European Journal of Marketing, 4(11/12), 125-134.

Oviatt, B. M., \& McDougall, P. P. (2005). Toward a theory of international new ventures. Journal of International Business Studies, 36(1), 29-41.

Podsakoff, P. M., MacKensie, S. B., Lee, J. Y., \& Podsakoff, N. P. (2003), Common method biases in behavioral research: A critical review of the literature and recommended remedies. Journal of Applied Psychology, 88(5), 879-903.

Sekaran, U. (2003). Research method for business: A skill building approach (4th ed.). John Wiley \& Sons.

Sullivan, D. (1994). Measuring the degree of internationalization of a firm. Journal of International Business 
Studies, 25(2), 325-342.

Taylor, E. S., \& Gollwitser, M. P. (1995). Effects of mindset on positive illusion. Journal of Personality and Social Psychology, 69(2), 213-226.

Tesfom, G., \& Lutz C. (2006), A classification of export marketing problems of small and medium-sized manufacturing firms in developing countries. International Journal of Emerging Markets, 1(3) 262281.

Tolstoy, D. (2019). The proactive initiation of SMEs' foreign business relationships. European Management Review, 16(4), 1159-1173.

Uganda Export Promotions Board Database (2018). The Uganda export directory, 2016-2017. Uganda Publishing and Printing Corporation.

Welch, L., \& Luostarinen, R. (1993). Internationalization: Evolution of a concept. In P. J. Buckley, \& P. N. Ghauri (Eds.), The internationalization of the firm: A reader (pp. 83-91). Academic Press.

Wood, S. W., \& Williams, W. D. (2014),. Opportunity evaluation as rule-based decision making. Journal of Management Studies 51(4), 573-602.

Williams, D. W. (2010). Why do different new ventures internationalize differently? A cognitive model of entrepreneurs' internationalization decisions. Dissertation Georgia State University. https://scholarworks. gsu.edu/managerialsci_diss $/ 21$

Yamane, T. (1973). Statistics: An introductory analysis (3rd ed.). Harper and Row.

Yang, L. D., Ju, M., \& Gao, Y. (2015). Export relational governance and control mechanisms: Substitutable and complementary effects. International Marketing Review, 32(6), 627-645.

Zahra, S. A., Korri, J. S., \& Yu, J. F. (2005). Cognition and international entrepreneurship: Implications for research on international opportunity recognition and exploitation. International Business Review, 14(2), 129-146. 